\title{
ARTICLE \\ Chilli powder and resistance: Mirch Masala, Shaheen Bagh, and the politics of space
}

\section{Uttaran Das Gupta ${ }^{1}$}

Accepted: 13 April 2021 / Published online: 19 May 2021

(c) O.P. Jindal Global University (JGU) 2021

\begin{abstract}
My article looks at the events around Shaheen Bagh through the frame of the 1987 Hindi feature film Mirch Masala and analyses the politics of space and gender in both. In late 2019-early 2020, elderly women of Shaheen Bagh, a Muslim 'ghetto' in south New Delhi, staged an unprecedented protest against the contentious Citizenship (Amendment) Act, 2019 (CAA). These women had never before been politically active, nor had any support from political or social organisations. However, their protest soon captured the imagination of not only other Indians but also the world. The peaceful sit-in, which survived repeated vilification, attacks, and even a communal riot, created for the first time a significant challenge to the Hindu majoritarian philosophy of Prime Minister Narendra Modi's Bharatiya Janata Party (BJP) and its parent organisation, the Rashtriya Swayamsevak Sangh (RSS). In March 2020, as the country went into a lockdown, the government finally managed to evacuate the protestors, but as several commentators have argued, Shaheen Bagh had ceased to be a geographical site and had become a reimagination of the nation itself. Mirch Masala, set in a village in western India in the 1940s, is considered to be one of the first feminist Hindi films. The narrative of the film revolves around a resistance set up by some of the village women against the local colonial official's lecherous desires for one of them. While there are obviously significant differences between the narrative of the film and the real-life protest, both allow us to study gendered spaces and reimaginations of citizenships.
\end{abstract}

Keywords Shaheen Bagh · Mirch Masala - Citizenship (Amendment) Act, 2019 $(\mathrm{CAA}) \cdot$ Delhi riots $\cdot$ Citizenship

Uttaran Das Gupta

udgupta@jgu.edu.in

1 O. P. Jindal Global University, Sonipat, India 


\section{Introduction}

When the sadistic subedar (Naseeruddin Shah) accosts Sonbai (Smita Patil), a poor village woman in Ketan Mehta-directed Mirch Masala (1987), demanding that she surrender to his desires, she slaps him and escapes. The subedar, a minor colonial official fond of caressing his impressive moustache, finds his masculinity challenged and sends his men on horses to capture her. A hunt ensues. Sonbai evades the soldiers and escapes into a spice-making factory in the village where she works. On hearing of her plight, the factory's elderly guard Abu Mian (Om Puri) - the only Muslim character in the film-shuts the gates before the soldiers can catch up. When they try to force their way in, he lets them know that he will not desist from firing his gun. Thus begins a lengthy siege of the factory. The status quo appeals to the subedar's sadism - it is like a cat and mouse game for him. (Earlier in the film, he viciously beats up a servant for merely breaking a gramophone record and orders a poor farmer to be tied to a pole in the midday sun for being unable to pay back a moneylender.) He sends emissary after emissary to the factory to persuade Abu Mian and the women to give up Sonbai. First comes the factory's owner, then the village headman (Suresh Oberoi). Abu Mian turns all of them back.

A similar status quo-albeit with some striking differences-was established, between December 2019 and March 2020, by the women of Shaheen Bagh, a neighbourhood $^{1}$ in the south of India's capital New Delhi. The area, inhabited mostly by Muslims, emerged as the epicentre of the nationwide protests against the CAA. This prompted Adityanath, the Chief Minister of India's largest state Uttar Pradesh and a leader of Prime Minister Narendra Modi's BJP, to claim:

These people (referring to male anti-CAA protesters) do not have the courage to participate in the protests themselves.... They started making the women of their houses sit at roads. The children have been made to sit too. It is a big crime that the men are sleeping under the quilt while women have been pushed forward. ${ }^{2}$

\footnotetext{
${ }^{1}$ For details on Shaheen Bagh, see Farah Farooqi, 'To Better Understand Shaheen Bagh Protest, We Must Understand the Locality Itself' (Caravan, 20 January 2020). https:/caravanmagazine.in/politics/ shaheen-bagh-locality-caa-protest. Accessed 02 April 2021; Fareeha Iftikar, 'Shaheen Bagh Living Up to Its Name, Says Man Who Christened the Colony' (Hindustan Times, 24 January 2020). https://www. hindustantimes.com/cities/shaheen-bagh-living-up-to-its-name-says-man-who-christened-the-colony/ story-PFsIKrwerxyiEx4sCTOYHP.html. Accessed 02 April 2021. Journalists Ziya Us Salam and Uzma Ausaf have chronicled how the Shaheen Bagh movement grew in their book Shaheen Bagh: From a Protest to a Movement (Bloomsbury India 2020). Writer and academic Rakhshanda Jalil also lived for some time in the Jamia neighbourhood, not too far from Shaheen Bagh, and writes about her experiences of ghettoisation of Muslims in New Delhi in the chapter 'Living in Jamia, Coping with Ghettoization', included in her book But You Don't Look Like a Muslim (HarperCollins 2019) 9-13. Another wonderful book on the ghettoisation of Muslims in Indian cities is Anasua Chatterjee's Margins of Citizenship: Muslim Experiences in Urban India (Routledge 2017).

2 “"Where Are the Men?" Yogi Adityanath's Swipe at Shaheen Bagh Protesters' (NDTV, 22 January 2020). https://www.ndtv.com/india-news/shaheen-bagh-caa-protest-where-are-the-men-yogi-adityanathsswipe-at-shaheen-bagh-protesters-2168215. Accessed 02 April 2021. More than 20 people were killed and many more imprisoned in Uttar Pradesh, where Muslims comprise 19 per cent of the population, during anti-CAA protests. Observers pointed out that police action against the protestors was particu-
} 
In a response, Kavita Panjabi, Professor of Comparative Literature at Jadavpur University in Kolkata, wrote:

A republic truly comes of age when its women too claim it.... When millions of women begin to insist that the state is a matter of res publica, a public affair, and not the private estate of rulers to decree ... then it marks the turning point in the history of the nation. When women take over public spaces in small towns and big cities across the country with the power we are witnessing today, then theirs is a force not to be underestimated. ${ }^{3}$

There are, of course, significant differences between what happened at Shaheen Bagh and the other protest sites, and the narrative of Mirch Masala; it would be anachronistic to expect that a film from the late 1980s could be mapped directly onto events occurring three decades later. In the film, Sonbai hides in the spice factory not out of any political motivation but to escape the immediate threat of sexual assault; the women of Shaheen Bagh were not protesting sexual violence but were definitely confronted with an existential crisis. The strategies used by the characters in the film and the women in real life are also markedly different-Sonbai and her comrades eventually resort to violence while the women at Shaheen Bagh resolutely stuck to Gandhian non-violence. Finally, the crisis in the film does not lead, in my opinion, to a satisfactory resolution, while the Shaheen Bagh protestors do manage to achieve their objective to a certain degree. Yet, a film like Mirch Masala, with its exploration of space, does allow us to meditate on sites-especially a site of protest or struggle-occupied exclusively or mostly by women. Such a site is uncommon-almost unimaginable - in cinema or real life; no one expected Shaheen Bagh to emerge as a metaphor for the anti-CAA protest and no one in the film imagined that the women would be able to resist the superior strength of the subedar and his soldiers. It is in this sphere beyond the imagination that the congruence between the narrative of the film and the occurrences in real life can be found. Compelling the audience and the citizens, respectively, to expand their imagination is the subversive potential of each.

\footnotetext{
Footnote 2 (continued)

larly brutal. Adityanath - a saffron-clad monk-became the chief minister of Uttar Pradesh after the BJP swept the elections to the state legislature in 2017. He has been accused of sparking riots and hate speech against Muslims. See Nilanjana Bhowmick, 'Why This Indian State Is Witnessing the Country's Most Violent Anti Citizenship-Law Protests' (Time, 01 January 2020). https://time.com/5757332/uttar-prade sh-citizenship-protests/. Accessed 02 April 2021.

${ }^{3}$ Kavita Panjabi, 'Women at Kolkata's Park Circus Prove the Indian Republic Has Come of Age' (The Wire, 27 January 2020). https://thewire.in/women/kolkata-park-circus-women-protest-caa. Accessed 02 April 2021.
} 


\section{Shaheen Bagh: From a ghetto to a protest site}

But before looking at the film, it is necessary for us to remember how Shaheen Bagh emerged as an unlikely site for the resistance against the CAA. The protests began on the night of 15 December 2019, after Delhi police entered the campus of the Jamia Millia Islamia University, where students had been protesting peacefully against the CAA. 'Not just students who had been protesting ... but those studying in the university library or praying in the mosque were at the receiving end of police fury,' write journalists Ziya Us Salam and Uzma Ausaf. ${ }^{4}$ The police, allegedly hurling the most communal of abuses at the students, used tear gas in the library, leaving hundreds suffocating.

Tables and chairs were smashed, windowpanes reduced to shards, bones were broken - a student even lost his eye. There were visuals of blood on the prayer carpets in the mosque.... Even as the images ... caused consternation among the locals, the stir spread to the most unimaginable of places-Shaheen Bagh. ${ }^{5}$

Jamia Millia Islamia University is about $3.2 \mathrm{~km}$ northwest of Shaheen Bagh, and many young people from the area study there.

When their [the women of Shaheen Bagh] children and grandchildren went to study in Jamia, they took pride in it. Also, there was unexpressed safety; they knew the youngsters had gone virtually next door to study.... Jamia offered the hope of a better future, and the reality of a secure and stable today. They could reasonably expect them to reach home safely after their classes. The policemen on the rampage in the university on 15 December 2019 shattered many such innocent dreams. ${ }^{6}$

A local resident, Mushtaq, recalled the horror and chaos of the night to journalist Seemi Pasha:

We reached the campus and started taking injured students to nearby hospitals.

... Some messages were sent out asking people to reach the bus stop at Shaheen Bagh.... We sat down on the pavements and on the road and started talking about what needed to be done. Some people arrived with anti-CAA posters and the Tricolours. Some suggested that we blocked the road in protest. We were sitting on the road already and we decided to continue sitting. ${ }^{7}$

The selection of the space for protests was quite spontaneous, but the women taking charge had a little more thought behind it:

\footnotetext{
4 Salam and Ausaf, Shaheen Bagh: From a Protest to a Movement (n 1) ix.

5 Ibid. ix-x.

6 Ibid. xii-xiii.

7 Seemi Pasha, 'Women, Violence and Democracy' in Seema Mustafa (ed), Shaheen Bagh and the Idea of India: Writings on a Movement for Justice, Liberty and Equality (Speaking Tiger Books 2020) 47-48.
} 
The men who had managed to block traffic for almost six days, following the police crackdown in Jamia, knew that the cops could scuttle their protests whenever they wanted, so a handful of women offered to sit there. Someone loaded a few carpets and blankets onto a rickshaw and brought them to the bus stop at Shaheen Bagh. Some fifteen or so women huddled under the cold winter sky on the first night.... By next evening, a tent had come up to protect them from the icy winds and fog. Women from the neighbourhood who were not able to sit out all day because of their household duties, started bringing hot tea and home-cooked food in the evenings. Someone set up a music system to play patriotic songs from old Bollywood films. ${ }^{8}$

The women of Shaheen Bagh inspired women from around the country to launch similar protests. Journalist Subhashini Ali provides a helpful list: 'Mohammad Ali Park and Ajit Nagar in Kanpur; Mansoor Park in Allahabad [Prayagraj]; Ghantaghar in Lucknow; Eidgah in Deoband; Yusufpur and Sabzibagh in Patna; Tajnagar Maidan and Idgah Maidan in Samastipur; Manek Bagh and Bada in Indore; Hauz Rani and Khejuri in Delhi ... and many, many more. ${ }^{9}$ Nazes Afroz, another journalist, provides an account of similar protests at Park Circus in Kolkata:

...the Shaheen Bagh protests in Delhi, led by local women, gave them [protestors] the idea of starting something similar in Kolkata. They chose Park Circus Maidan as the site because it was one of the busiest crossroads of the city. A protest that started with a sit-in of a few women soon attracted attention of the local media, the city's civil society, and was joined by university students and cultural activists. By the time I arrived in Kolkata, a couple of weeks later, people in every corner of Kolkata were talking about the women of Park Circus. $^{10}$

It was, as Kavita Panjabi had written, women reclaiming the republic.

\section{A spice factory, a safe space}

In Mirch Masala, the factory is a wholly female space; Abu Mian is the only exception. The women prepare heaps of red chilli that they will dry, crush, and make into powder. They sing as they work, the place has a playful atmosphere. Just before Sonbai arrives, pursued by the subedar's men, one of the elderly women warns her colleagues: 'These chillies are very strong.' Scholar Anita Mannur in her essay on Mirch Masala describes the spice factory as a site of struggle:

\footnotetext{
${ }^{8}$ Ibid. 48.

9 Subhashini Ali, 'The Shaheen Baghs of Uttar Pradesh' in Mustafa, Shaheen Bagh and the Idea of India (n 7) 201.

${ }^{10}$ Nazes Afroz, 'Rokeya's Children in Park Circus' in Mustafa, Shaheen Bagh and the Idea of India (n 7) 194-195.
} 
[T]his film poignantly alludes to how chilies are more than a mere spice, additive, or flavoring... chilies figure into this narrative less as objects to make the world 'colourful' than as a form of life-affirming fieriness. The commodity which the women labour to produce-dried chilies-is transformed by the film's close into a harbinger of change. The chilies are a source of income and a weapon to resist patriarchal oppression, and the factory is transformed from a mere workplace into a site of struggle. ${ }^{11}$

The defiance of the women at the factory - at first reluctant, and then more resolute-leaks out of the shut gates and infects the women of the village. In the beginning of the film, the women of the village have little to no agency-they are denied education or the right to choose their partners and are married off early. When the mukhiya's (village headman's) wife, Saraswati (Deepti Naval), in an act of microdefiance, admits her daughter in the village school, her husband drags the child back home and threatens his wife with dire consequences if she dares to transgress her domestic limitations. The mukhiya also ensures a steady supply of village women to the subedar to keep him placated. When another girl from the village, Radha (Supriya Pathak), dares to fall in love with the mukhiya's brother (Mohan Gokhale), and her father discovers them in an intimate position, he beats her black and blue.

Yet, when the village council decides that Sonbai must be surrendered to the subedar, and the men of the village march towards the factory, the women-led by Saraswati-confront them. They are armed with household vessels which they clang as they obstruct the path of the men. Mannur traces the image of women armed with household utensils to protests organised by Indian feminists in the 1970s:

The history of this iconic image of women transforming cooking utensils into objects of protest is also intimately linked with Indian women's movements from the 1970s. In 1973, the Indian feminist-activist Mrinal Gore, a member of the Socialist Party of India, joined forces with the women of the Communist Party of India (CPIM) to establish the Mahagai Virodhi Andolan (United Women's Anti-Price-Rise Front)... Many activists additionally credit Gore for her creative protest methods using the latni morcha and handi morcha whereby women would brandish rolling pins and small water vessels in their agitations against discriminatory gender practices. ${ }^{12}$

The men of the village in Mirch Masala do not tolerate this transgression. The women are assaulted and imprisoned in their homes by their fathers, brothers, husbands. The brief resistance is broken up too easily. But, as Saraswati watches the men march on towards the factory from the lattice window of her house, she is no more a mute spectator-she keeps banging the lattice with her fists and grunting in defiance. The women of the village may have been crushed this time, but they will learn to organise better.

\footnotetext{
11 Anita Mannur, 'Red Hot Chili Peppers: Visualizing Class Critique and Female Labor' in Culinary Fictions: Food in South Asian Diasporic Culture (Temple University Press 2010) 126.

12 Ibid. 123-124.
} 
When his emissaries fail to bring about the desired result, the subedar turns up at the gates of the factory with his platoon. He orders those cooped up inside to open the gates as he counts up to ten. When they don't, he orders his men to break it open. The men attack the gates with a log (an obvious phallic symbol), as they rush towards it, raising a war cry. The gate collapses. Abu Mian, standing with his rifle, opens fire, dislodging the subedar from his horse. The soldiers return fire, killing the guard. For the women inside_-particularly Sonbai, waiting for the inevitable with a sickle in her hand-all seems lost as the subedar enters the factory. But even before he can approach Sonbai, the other women in the factory attack him. Without guns or any other weapon at their disposal, they use what they have: basket after basket of chilli powder is flung upon the subedar. As Mannur notes, they literally burn out his eyes - the source of his patriarchal gaze. I would like to add that the audience is also implicated in the process - in shot after shot, the women throw the spice at the camera, which is supposed to provide the perspective of the subedar, but at the same time, provides the audience with an experience of the rage of women charging at them, armed with chilli powder. The film ends with the cries of anguish of the subedar as he falls to his knees, and Sonbai lurking behind him, a sickle-a symbol of the Marxist movement in the country-in her hand. Is she about to behead him?

Both Mannur and film scholar Ranjani Mazumdar claim that this is a moment filled with possibilities. The former writes:

Mehta's film significantly departs from the conventions of most mainstream films in its refusal to provide a sentimental or moralizing ending. The film ends with a shot of Naseeruddin Shah screaming, in response to having had fine particulates of dried chilies hurled into his eyes. Yet it is not Sonbai who launches this attack on the subedar. Rather, the women of the chili factory rally behind her to blind the subedar's penetrating gaze. Sonbai, significantly, does not take up arms at the end of the film. Instead, she is framed in the final shots with a sickle in hand, embodying her position as an agent of revolutionary change. This final image positions Sonbai as another actor in a series of revolutionary acts led by peasant insurgents. While it would be tempting to interpret this as a sign that the women had triumphed over the subedar, the film cannot be so easily contained. The final gesture of the film remains openended, not fully interpretable, creating instead a web of potentiality and signification regarding the meaning of the final gesture. ${ }^{13}$

In a review of the film, Mazumdar writes:

As the subedar collapses, screaming in agony, Mehta cuts to a close-up shot of Sonbai looking straight at the audience, with a slight smile on her face. The audience at this point wants to know what happens after this-do the soldiers attack? What do the village people do? What happens to Sonbai? But Mehta

13 Ibid. 125. 
consciously breaks the narrative, to leave it open-ended so that the audience is able to participate and reflect on the issues being raised. ${ }^{14}$

But this seems to me to be a sort of false hope. Sonbai's fate is sealed from the moment she slaps the subedar; no one in the audience or the village can imagine that she will escape the repercussion of such an action. The ending is not really openended: An attack on-or murder of - a colonial official can result only in retribution from the state. Another film that dramatises gender conflict in a village resulting in women unleashing violence on men who had oppressed them till then is Mrityudand (1997), directed by Prakash Jha. Set in a village in Bihar in 1996, the film begins with a group of men lynching two women whom they accuse of witchcraft. This is still a very common crime in India-in 2019, 102 women suspected of being witches were killed in the country, according to a report of the National Crime Records Bureau. ${ }^{15}$ By the end of the film, the protagonist Ketki Singh (Madhuri Dixit) manages to rally the women of the village to fight back against contractor Tirpat Singh (Mohan Joshi) and the priest of the local temple, Abhay Singh (Mohan Agashe). In the climactic moments of Mrityudand, Ketki shoots Tirpat-but no matter how revolutionary or dramatic her actions, they entail legal repercussions.

The women at Shaheen Bagh, however, manage to use their non-violent protest for greater and more permanent political gains. The situation on the ground turned macabre both at Shaheen Bagh and a few kilometres away at Jamia Millia Islamia University, where students and local residents had set up another protest site in late January and February 2020, before the protestors were finally evicted in March. On 30 January 2020 - the anniversary of Mahatma Gandhi's martyrdom - an armed young man (later claiming to be a minor) opened fire on protesting students at Jamia. Photographs and videos of the incident showed the policemen posted at the site literally standing with folded hands. ${ }^{16}$ On 1 February, one Kapil Gujjar opened fire at the protestors at Shaheen Bagh. While he was being led away by the police, he managed to shout into the microphones of gathered journalists that this nation belonged to Hindus. ${ }^{17}$ Another firing incident was reported from the campus of Jamia on 3 February $2020 .^{18}$ The incidents were not unrelated to the hate speech that many prominent leaders of the BJP were spewing at their election rallies in the

\footnotetext{
14 Ranjani Mazumdar, 'Dialectic of Public and Private: Representation of Women in Bhoomika and Mirch Masala' (1991) 26(43) Economic and Political Weekly WS81.

15 National Crime Records Bureau, Crime in India 2019 (vol. 1) 161. https://ncrb.gov.in/sites/default/ files/CII\%202019\%20Volume\%201.pdf. Accessed 02 April 2021.

16 Rana Ayyub, 'The Hate That Inspired Gandhi’s Assassin Is Rising Again' (Washington Post, 31 January 2020). https://www.washingtonpost.com/opinions/2020/01/31/hate-that-inspired-gandhis-assassin-isrising-again/. Accessed 02 April 2021.

17 'Delhi: Gunman Opens Fire in Shaheen Bagh, Two Days after Jamia Shooting' (Scroll.in, 01 February 2020). https://scroll.in/latest/951841/delhi-gunman-opens-fire-in-shaheen-bagh-days-after-jamia-shoot ing. Accessed 02 April 2021. Gujjar joined the BJP on 31 December 2020, but was expelled a few hours later.

18 'Another Firing at Jamia Protest, Police Have Found No Bullet Shells or Evidence at Spot' (India Today, 03 February 2020). https://www.indiatoday.in/india/story/another-firing-at-jamia-caa-protest-10points-1642710-2020-02-03. Accessed 02 April 2021.
} 
run-up to the Delhi Assembly elections on 8 February 2020. Minister of State for Finance and Corporate Affairs in Modi's cabinet, Anurag Thakur, was banned by the Election Commission from campaigning for a few days after he chanted a slogan on 27 January demanding that those betraying the nation be shot. ${ }^{19}$ The same slogan was heard at a rally of Union Home Minister Amit Shah, whose campaign focussed several times on the protest at Shaheen Bagh. Another BJP leader, Kapil Mishra, described the site as a mini-Pakistan. ${ }^{20}$

\section{Finding India in 'A Mini Pakistan'}

Describing a place as 'Pakistan' attaches to it pejorative connotations in the minds of those subscribing to Hindutva, the militant Hindu majoritarian philosophy that informs policies of the BJP and its parent organisation, the RSS. It is also directly related to the process of ghettoisation of the Muslim population in Indian cities. Urban spaces in the country are sharply divided on religious and caste lines, with 'Muslim residential areas' often demarcated, in official narratives or popular imagination, in terms such as 'mini-Pakistan'. ${ }^{21}$ Political scientists Christophe Jaffrelot and Laurent Gayer in a study of Muslims in urban Indian spaces claim that in the north and west of India, where outbreak of communal riots has been frequent since Independence, communities have known less peace and have been forced into ghettos or slums that are acutely visible and patrolled. ${ }^{22}$ In Delhi, this process of ghettoisation has happened in phases. Historian Vazira Fazila-Yacoobali Zamindar claims that in the Partition-related violence in Delhi, almost 20,000 Muslims were killed and many more were forced out of 'mixed' neighbourhoods into areas where their communities concentrated, initiating a process of ghettoisation. ${ }^{23} \mathrm{~A}$ second phase-perhaps not as widely known as the first one-was during the beautification drive initiated by Sanjay Gandhi, Congress leader and son of former Prime Minister Indira Gandhi, during the Emergency (1975-1977). Carried out by Jagmohan Malhotra, who then headed the Delhi Development Authority and would later serve as

\footnotetext{
19 'EC Bars Anurag Thakur, Parvesh Verma from Campaigning for a Few Days (Economic Times, 31 January 2020). https://economictimes.indiatimes.com/news/elections/assembly-elections/delhi/campa ign-ban-on-union-min-anurag-thakur-bjp-mp-parvesh-verma/articleshow $/ 73765990 . \mathrm{cms}$ ?from $=\mathrm{mdr}$. Accessed 02 April 2021.

20 “"Pakistan Has Entered Shaheen Bagh”: BJP's Kapil Mishra Raises Political Temperature in Delhi' (Hindustan Times, 23 January 2020). https://www.hindustantimes.com/assembly-elections/delhi-assem bly-elections-2020-pakistan-has-entered-shaheen-bagh-bjp-s-kapil-mishra-raises-political-temperaturein-delhi/story-tqbMPrksrxXLfvqIezRmqK.html. Accessed 02 April 2021.

21 See Sriharsha Devulapalli, 'Geography of Caste in Urban India' (Mint, 29 September 2019). https:// www.livemint.com/news/india/the-geography-of-caste-in-urban-india-1569564507580.html. Accessed 02 April 2021. See also Atikh Rashid, 'How Muslim Ghettos Came About in Delhi' (Indian Express, 03 March 2020). https://indianexpress.com/article/india/muslim-ghettos-of-delhi-6297633/. Accessed 02 April 2021.

22 Christopher Jaffrelot and Laurent Gayer (eds), Muslims in Indian Cities: Trajectories of Marginalisation (HarperCollins 2012).

23 Vazira Fazila-Yacoobali Zamindar, The Long Partition and the Making of Modern South Asia: Refugees, Boundaries, Histories (Columbia University Press 2007).
} 
member of Parliament from the BJP, it displaced thousands of residents from the Jama Masjid and Turkman Gate area to Seelampur and Welcome in northeast Delhi. In late February 2020, as the protests against the CAA snowballed into anti-Muslim riots, these were the areas worst affected by the violence. This is a process of delegitimisation of the rights of people inhabiting these areas, making them vulnerable to discrimination and violence.

Despite this discrimination, prejudice, and threat of violence, Shaheen Bagh managed to achieve its objective of scuttling the CAA to a great extent. It did so precisely by forcing participants and detractors to expand their imagination. Soumyabrata Choudhury, Professor of Arts and Aesthetics at Jawaharlal Nehru University, New Delhi, claims that the only way to experience what happened at Shaheen Bagh was through a subjective participation in the ritualistic nature of the space:

It is possible to assert that first an objective material cause of subjective anxiety among the Muslim population in India emerges - the CAA, in the background of the National Register for Citizens (NRC) and later the National Population Register (NPR) — and then, as the government remained impervious to all appeals asking for a revocation of the amended act, anxiety turned to anger such that people came out, particularly the women of Shaheen Bagh, who refused to disperse till they were heard. They assembled-and Shaheen Bagh happened. $^{24}$

Choudhury, however, claims that if we think of Shaheen Bagh only as a reaction we are likely to miss the 'historical possibility' ${ }^{25}$ of the space. In Choudhury's thesis, Shaheen Bagh ceases to be merely a space-be it the 'mini-Pakistan' of Hindutva fetish or the 'reclaiming of the republic' proposed by others-and becomes an emblem. 'Justice is our new common feeling,' he adds.

Here and now, at Shaheen Bagh, justice exists! That is why, we can find the courage to stand here exposed to the police and the virus and continue to speak against injustice. Even if you were to take us away and put us in jail or quarantine, nothing will change. Wherever the thought of justice begins to exist, Shaheen Bagh will begin to exist. ${ }^{26}$

In the beginning of my article, I had claimed that it is only in the realm of imagination that one can participate in the subversive potential of spaces such as Shaheen Bagh or the spice factory in Mirch Masala. In the film, the audience is invited to participate in the resistance of the village women; the intrusions of the camera into the spice factory allow us an imaginative bridge into the feminine space of resistance. The factory, one might suppose, existed in the village for a while before the incident between Sonbai and the subedar, but neither the women nor the male residents of the village-nor the audience-imagined that it could be a space of resistance.

\footnotetext{
${ }^{24}$ Soumyabrata Choudhury, Now It's Come to Distances: Notes on Shaheen Bagh and Coronavirus, Association and Isolation (Navayana 2020) 55.

25 Ibid. 56.

26 Ibid. 59-60.
} 
When it does become one, the audience has the privilege of a subjective perspective. Unlike the villagers who do not know what is happening inside, we do. We are privy to the hopes and fears of the women, and perhaps even sympathetic to their condition. It is only in the final few shots, when the women throw red chilli powder at the subedar, that the audience is implicated as well. This sudden, rude disruption to the objectivity is a challenge to the gaze of the audience as well, which is traditionally a male gaze. The audience is forced to-or at least nudged to- - stop watching and start thinking.

Something similar happens in Shaheen Bagh-but with an essential difference. The viral replication of the Shaheen Bagh model of resistance across the country and its transformation from a little-known ghetto to a reimagination of the republic is proof enough of its potential. Before the women of Shaheen Bagh, who had no political experience or even much agency, organised themselves and adopted these methods of contentious politics, no one-perhaps not even them-would have imagined how they would capture the imagination of the entire nation and even the world. The geographical space of Shaheen Bagh does not change-it continues to be a ghetto, accompanied by all the markers and stigma attached to such a classification. However, in the realm of the imagination, it is transformed into an alternative, a pilgrimage for those citizens of New Delhi who disagree with a Hindutva imagination of the country, an invitation to participate in the process of imagination that results in the creation of nations. As Choudhury asserts - and I agree-Shaheen Bagh is no more only a ghetto in New Delhi, it is emblematic of all such ghettos and spaces around the country where citizens resisted the CAA. Instead of a rude disruption of perspective as in Mirch Masala, it becomes more inclusive, both physically and emotionally.

Despite ceasing to be an actual site of resistance since March 2020 and the pandemic-induced lockdown, Shaheen Bagh has lost none of this potential. One might still be sceptical about my claim that the protestors at Shaheen Bagh managed to achieve their objectives to a great extent. Some of the developments would justify this scepticism. As the government evoked the Epidemic Diseases Act, 1897, to enforce a lockdown in New Delhi, the sit-in was finally cleared on 24 March 2020 - 101 days after the protest began. ${ }^{27}$ The Delhi police also registered cases and arrested several activists and citizens who took part in the anti-CAA protests; several of them were accused of provoking violence or being instigators of the February riots. ${ }^{28}$ Finally, the government has shown no signs of withdrawing the CAA, the NRC (National Register for Citizens), or the NPR (National Population Register), and, in fact, has repeatedly claimed that these will be implemented. Home Minister

\footnotetext{
${ }^{27}$ Mukesh Singh Sengar and Saurabh Shukla, 'Shaheen Bagh Anti-CAA Protesters Removed amid Delhi Lockdown' (NDTV, 24 March 2020). https://www.ndtv.com/india-news/delhis-shaheen-baghheart-of-anti-caa-protests-cleared-after-101-days-amid-lockdown-over-coronavirus-2199558. Accessed 02 April 2021.

28 Nileena MS, 'Amid Lockdown, Delhi Police Target and Arrest Anti-CAA Protesters from Jamia Nagar' (Caravan, 15 April 2020). https://caravanmagazine.in/politics/anti-caa-protesters-jamia-arrested. Accessed 02 April 2021.
} 
Amit Shah, addressing an election rally in the eastern state of West Bengal on 11 February 2021, said:

The delay in framing CAA rules because of Covid-19 meant opposition leaders ... went all out in claiming that the BJP was not implementing [the] Citizenship Amendment Act. Let me tell you, we will honour our commitments, bring in the CAA. It will be a reality.... First let the vaccination process be complete; then we will frame rules and implement CAA. ${ }^{29}$

He was also quick to add that no Muslim would lose their citizenship.

Covid-19 might have provided the government with a convenient excuse, but there are definitely several other reasons why the government has dragged its feet on implementing the law, writes journalist Shoaib Daniyal. ${ }^{30}$ The rules for a law need to be framed within six months of its being passed by the Parliament though it is possible to get extensions, which is what the government has done in the case of the CAA. The pandemic and the lockdown happened four months after the CAA was promulgated; so why the delay? And, even during the pandemic, the government has passed several laws such as the controversial farm bills, leading to massive protests. ${ }^{31}$ Daniyal suggests several reasons - stringent international focus, opposition from rivals of the BJP, and refusal of state governments to implement the law, ${ }^{32}$ and complications within the structure of the law itself. But perhaps above all other reasons, is the idea of Shaheen Bagh-more than the geographical location-that has deterred the BJP and its leaders despite their overwhelming political majority. What Shaheen Bagh has managed emphatically is to create a deadlock around the law from which the government can emerge but only at a significant cost: if it withdraws the law, it risks the alienation of a core vote bank; if it pushes the law through, severe international censure ${ }^{33}$ and the reopening of spaces of resistance. It is imaginable that the government might be able to prevent the associations in certain geographical spaces, ${ }^{34}$ but as we have already seen, that is irrelevant. The idea

\footnotetext{
29 Abhishek Law, 'CAA Will Be Implemented after Covid Vaccine Exercise: Amit Shah' (The Hindu Business Line, 11 February 2021). https://www.thehindubusinessline.com/news/caa-will-be-imple mented-after-covid-vaccine-exercise-amit-shah/article33812619.ece. Accessed 02 April 2021.

30 Shoaib Daniyal, 'A Year Ago, the BJP Focussed Its Politics on the CAA. So Why Hasn't It Been Implemented Yet?' (Scroll.in, 11 December 2020). https://scroll.in/article/980659/a-year-ago-the-bjpfocussed-its-politics-on-the-caa-so-why-hasnt-it-been-implemented-yet. Accessed 02 April 2021.

31 Simran Jeet Singh, 'The Farmers' Protests Are a Turning Point for India's Democracy — and the World Can No Longer Ignore That' (Time, 11 February 2021). https://time.com/5938041/india-farmer-protestsdemocracy/. Accessed 02 April 2021.

32 'Kerala Will Not Implement CAA, Says CM' (The Hindu, 13 February 2021). https://www.thehindu. com/news/national/kerala/state-will-not-implement-caa-says-cm/article33831976.ece. Accessed 02 April 2021.

33 The annual report by the United States Commission on International Religious Freedom (USCIRF) named India as a 'country of particular concern', alongside Pakistan, China, and North Korea. This is the first time since 2004 that India has appeared in this category. In the India chapter of its report, the USCIRF makes special mention of the CAA and Home Minister Amit Shah's description of minorities as 'termites'. https://www.uscirf.gov/countries/india. Accessed 02 April 2021.

34 The Supreme Court ruled in October 2020 that a Shaheen Bagh-type protest, blocking thoroughfares, cannot continue indefinitely. See Debayan Roy, 'Constitution Envisages Right to Protest but with Certain Duties: Supreme Court Dismisses Review Petition against Verdict on Shaheen Bagh Protests' (Bar
} 
of Shaheen Bagh has transcended its geographical limitations and now exists in the realm of ideas.

Publisher's Note Springer Nature remains neutral with regard to jurisdictional claims in published maps and institutional affiliations.

Footnote 34 (continued)

and Bench, 13 February 2021). https://www.barandbench.com/news/litigation/supreme-court-dismissesreview-petition-against-judgment-shaheen-bagh-protests. Accessed 02 April 2021. At the same time, however, farmers protesting against the farm laws have blocked highways leading into New Delhi for months, and the government has been unwilling or unable to evacuate them. 